\title{
Analysis of Factors Affecting the Development of MSME Business Scale in the Agricultural Sector of Soppeng Regency
}

\author{
Sitti Hajerah Hasyim ${ }^{1, *}$, Muhammad $\operatorname{Hasan}^{2}$, Nur Arisah ${ }^{2}$, Nuraisyiah ${ }^{1}$ \\ ${ }^{1}$ Department of Economics Education, Faculty of Economics, Universitas Negeri Makassar \\ ${ }^{2}$ Department of Economics Education, Faculty of Economics, Universitas Negeri Makassar \\ "Corresponding author.Email:hajerah.hasyim@unm.ac.id
}

\begin{abstract}
This study aims to determine the effect of capital, quality of human resources, business management, level of competitiveness and technology on the development of MSME business scale in the agricultural sector in Soppeng Regency. This study was conducted using a quantitative approach, and was designed as an explanatory study. This study takes information from 30 purposive samples (purposive sampling) from SMEs in the agricultural sector located in Lilirilau sub-district, Soppeng Regency. Research data were collected through questionnaires distributed online which had been tested for validity and reliability, then analyzed using the SPSS Program. The results of this study indicate that capital, quality of human resources, business management, level of competitiveness and technology have a positive and significant impact on the development of MSME business scale in the agricultural sector in Soppeng Regency.
\end{abstract}

Keywords: Capital, quality of human resources, business management, level of competitiveness, technology, business scale development

\section{INTRODUCTION}

MSMEs (Micro, Small and Medium Enterprises) are part of national businesses that play an important role in realizing national development. In Indonesia, it still depends on the commodities cultivated and is mostly engaged in the agricultural sector, so that MSMEs in their development cannot be separated from various obstacles such as technical, technological, management and marketing so that it needs special attention in order to continue to grow and develop its business. MSMEs in Indonesia are mostly engaged in the agricultural sector. The agricultural sector plays an important role as a provider of food for the community and raw materials for industry [1]. The agricultural sector is still the mainstay of job creation in a sizeable amount compared to other sectors. other sectors in the Indonesian economy. This creates opportunities for the agricultural sector in its influence on the economy in Indonesia. The agricultural sector faces various changes as a result of globalization, namely the increasingly open competitive market, the increasing demands for agricultural policies based on market mechanisms (market oriented policy) and the increasing role of consumer tastes (demand driven). in determining activities in the agricultural sector. The agricultural sector still has the potential to be improved if it is successful in overcoming constraints including productivity, business efficiency, agricultural land conversion, limited agricultural facilities and infrastructure as well as limited agricultural capital and infrastructure. Agriculture is getting narrower, limited access to productive resources, especially access to capital, is accompanied by low quality of human resources, low technology mastery, decline in natural forest products while plantation forest products and nontimber forest products have not been used optimally and weak infrastructure in the area. agricultural sector in particular and rural areas in general [2]. The economy is considered to be experiencing growth if all real remuneration for the use of production factors in a given year is greater than the previous year [3].

Each region has different regional potentials, such as agriculture, animal husbandry, handicraft industry, various food processing businesses and various others. In the same way, Soppeng Regency is one of the regencies in South Sulawesi which is experiencing rapid 
development in agriculture [4]. In 2019, the land in Soppeng Regency is dominated by agricultural land, both agricultural land in the form of rice fields and nonagricultural land. rice fields. Soppeng Regency is undergoing an economic transformation from a potential sector to a progressive sector. The agriculture, forestry and fishery sectors are potential sectors and have the largest contribution to the GRDP of Soppeng Regency but are classified as economic sectors that move slowly, have negative competitive advantages or do not have high competitiveness, and belongs to a non-progressive economic sector [5].

The potential area of Soppeng Regency with an area of 150,000 ha is mostly used in the agricultural sector. In Soppeng Regency, there were several commodities that could be classified as mainstay commodities which were subsequently designated as leading commodities. The leading commodities in the food crop sector of Soppeng Regency include rice, corn, peanuts, soybeans and cassava. In 2020, the plantation area in Soppeng Regency is $22,231.77$ hectares with a total production of $10,700.22$ tons.

To measure the development of the business scale of SMEs in the agricultural sector, it can be seen in terms of the amount of production, sales and profits obtained by farming business actors. Performance of MSMEs [6]. The scale of business is one indication of the development of a company where a large company will have an impact on the employees involved [6].

MSMEs The agricultural sector in reality still faces many problems in developing its business. The problem faced is low capital. MSMEs The agricultural sector still faces obstacles in capital, both for working capital and investment capital. Capital limitations can occur due to declining sales levels, so that capital turnover is hampered [7]. In this case, farmers also have difficulty in obtaining capital because the capital is obtained by each farmer's own business [8]. In addition, in accessing capital loans, farmers must be more selective in choosing loans because it is related to the loyalty of the farmers themselves or the ability to repay loan capital and the quality of services provided by financial or banking institutions that are different from one another [9]. Where capital is one of the most important things in running a business. So in this case Cooperation between farmers and the government local is very much needed in needs big capital.

Another obstacle faced is the low quality of human resources. Several studies have shown that human resource development or improving the quality of human resources through training has an effect on employee performance, productivity, and organizational performance. There are two things that can be seen in relation to these human resources, namely the amount available and the quality of the human resources themselves. These two things are often used as indicators in assessing the problems that exist in agricultural activities. There is a close influence between the quality of human resources and the performance of SMEs. In this case, the quality of Human Resources is the ability of business actors to run their businesses by using the knowledge, education and skills they have [10]. Improving the quality of human resources is formal education and experience as farmers which greatly affect the productivity and profits of farming [11]. Farmers are human resources who play an important role in determining the success of a farming activity, because farmers are workers as well as managers in the farming business itself. Therefore, one of the efforts to participate in improving the managerial capabilities of MSME actors is to conduct business management training and business development strategies for MSMEs [12].

In addition, SMEs in the agricultural sector are still constrained in their business management, so positive efforts and steps are needed to improve their existence. Good management in running MSMEs is very much needed in order to be able to develop MSMEs so that they are able to increase the contribution of MSMEs to a country's economic growth. Because MSMEs are still revolving around technical aspects of production, financial aspects and marketing aspects [13]. Therefore, management of agricultural products is certainly needed so that when entering the harvest season the farmers do not experience difficulties in marketing their agricultural products because there are middlemen who are also present which causes difficulties in the life of the farming community, the middlemen buy agricultural products directly from farmers at low prices and resell them. market at high prices so that the profits obtained by farmers decrease.

The limited level of competitiveness is also an obstacle in the development of the MSME business scale in the agricultural sector. The implementation of the ASEAN Economic Community (AEC) will have an impact on micro, small and medium enterprises (MSMEs). Therefore, MSMEs need competitiveness in order to survive in market competition. One effort to be able to compete is to increase competitiveness, both the competitiveness of MSMEs and the competitiveness of their products through innovation. This is because the measurement of farm competitiveness is important to measure the ability of a farming commodity to generate maximum profit from the farm. Farmer competitiveness is the level of farmer's ability to produce agricultural products based on cost advantage. Competitiveness can be measured through two approaches, namely comparative advantage and competitive advantage. Comparative advantage measures the efficiency of a commodity based on economic analysis using shadow prices, while competitive advantage is used to measure the feasibility of an activity or private profit calculated based on private prices [14]. 
The last obstacle is the limited technology or machines used. The need for important facilities is conveyed to the agricultural extension agency because the facilities are a supporter in the business activities of the agricultural extension agency, but in fact not all of the farming communities are able to independently buy tractors, pumps etc. still need assistance from the government and always require escort in matters relating to agriculture. The application of technology in agriculture has not been maximized not because of mastery of technology but in inadequate facilities and infrastructure. In the context of developing the technology capacity of the SME sector, there are two things that are the subject of discussion, namely the ability to access information, and the application of management information systems [15]. This technological development will have a positive impact on MSMEs. The biggest thing that can be felt by MSMEs is in the marketing sector. The development of technology will make MSME products possible to enter the global market.

The number of MSMEs in the agricultural sector in Soppeng Regency from year to year continues to increase but has not been balanced with developments, especially in terms of quality development, this happens because MSMEs are still facing the classic problem of low productivity. Human Resources, Business Management, Competitiveness Level and Technology or machines used.

Therefore, this study discusses the factors that influence the development of the MSME business scale in the agricultural sector in Soppeng Regency. With the results of this study, it can be used by business actors to develop their own businesses more significantly, it can also be used by the government to be used as a basis for making policies and regulations that are more supportive of the development of MSMEs in the agricultural sector in Soppeng Regency.

Based on the background above, the authors are interested in conducting a research entitled "Analysis of Factors Affecting the Development of Small Business Scale of Agriculture Sector in Soppeng Regency".

\section{METHODOLOGY}

This study was conducted using a quantitative approach. This study aims to determine the effect of Capital (X1), Quality of Human Resources (X2), Business Management (X3), Competitiveness Level (X4) and Technology (X5) on Business Scale Development (Y) MSMEs in the Agricultural Sector in Soppeng Regency. In accordance with these objectives, this study was designed as an explanatory research.

The population of this research is the agricultural sector SMEs in Soppeng Regency, especially in the Lilirilau sub-district. The sampling method is purposive (purposive sampling). According to Rohim, A., \& Kurniawan, I. purposive sampling is a sampling technique with considerations or criteria- certain criteria. Purposive sampling is sampling with certain considerations [16]. These considerations are based on the interests or objectives of the research. The criteria for sampling this research are respondents who are SMEs in the agricultural sector in Lilirilau District, Soppeng Regency, who have business types in the form of selling rice, vegetables, fruits, agricultural businesses. rice, corn, cucumbers, bitter melon, vegetables, ornamental plants, and various other types of SMEs in the agricultural sector and who are considered to know information and data that have direct involvement and know the problem in depth and can be trusted as sources of data. The samples in this study There are 30 SMEs in the agricultural sector located in the Lilirilau subdistrict, Soppeng Regency.

This study uses primary data and secondary data. Primary data is data obtained directly by distributing questionnaires online. The preparation of the questionnaire is based on indicators of the factors studied in this study. For each questionnaire item, five alternative answers are provided. and the weighting of the scores so that each variable is measured on an interval scale. Meanwhile, secondary data is supporting data originating from relevant agencies and obtained from various publications including books, research results, websites, and data from government institutions such as data from the Agriculture Service.

Data analysis was performed using descriptive statistics with SPSS analysis tools. The data analysis used is validity test, reliability test, hypothesis test, coefficient of determination test, and multiple linear regression test.

The stages in data analysis are grouping data based on variables and types of respondents, tabulating data based on variables from all respondents, presenting data for each variable, performing calculations to answer the problem formulation and performing calculations for hypotheses that have been proposed [17].

\section{RESULTS AND DISCUSSION}

\subsection{Effect of capital on business scale development}

The findings of this study indicate that capital has a positive and significant effect on the development of MSME business scale in the agricultural sector in Soppeng district with a positive coefficient value of 0.262 and a significance value of 0.005 . This means that capital is one of the most important things in running a business. This finding is in line with studies conducted by previous researchers who stated that capital is one of the most important things in running a business because capital can be used to finance all forms of business expenses [18]. 
The capital used in running the farm can be sourced from own capital or capital loans. The amount of farming capital used is adjusted to production needs. Capital limitations can occur due to declining sales levels, so that capital turnover is hampered. During the pandemic, farmers experienced a decline in sales and did not proportional to the capital spent when cultivating [19]. In this case, farmers also have difficulty in obtaining capital because the capital is obtained by each farmer's own business [1]. There are various types of capital loans that can be obtained. by entrepreneurs. However, in accessing capital loans, farmers must be more selective in choosing loans because it is related to the loyalty of the farmers themselves or the ability to repay loan capital and the quality of services provided by financial or banking institutions that are different from one another [20].

\subsection{The influence of HR Quality on the development of business scale}

The findings of this study also show that the quality of human resources has a positive and significant effect on the development of the MSME business scale in the agricultural sector in Soppeng district with a positive coefficient value of 0.153 and a significance value of 0.002 . This means that there is a close influence between the quality of human resources and development of business scale. In this case the quality of Human Resources is the ability of farming actors to run their businesses by using the knowledge, training and skills they have. These findings are in line with studies conducted by previous researchers who stated that the quality of human resources affect the development of business scale [21].

There are two things that can be seen in relation to these human resources, namely the amount available and the quality of the human resources themselves. These two things are often used as indicators in assessing the problems that exist in agricultural activities. Improving the quality of human resources is formal education and experience as farmers which greatly affect the productivity and profits of farming [7]. Farmers are human resources who play an important role In determining the success of a farming activity, because farmers are workers and at the same time managers in the farming business itself. Therefore, one of the efforts to participate in improving the managerial capabilities of MSME actors is to conduct business management training and business development strategies for MSMEs [3]. Likewise, farming skills can be improved by routinely participating in training. In addition, knowledge related to agriculture can be obtained from counseling, agricultural websites and from fellow farming actors.

\subsection{The influence of business management on the development of business scale}

Business management has a positive and significant effect on the development of MSME business scale in the agricultural sector in Soppeng Regency with a coefficient value of 0.383 and a significance value of 0.004 . This means that with business management, business actors can understand how to manage their business in terms of product and production management, marketing management, especially the problem of using social media as a promotional tool that can be quite effective with good management, financial management, especially regarding financial records. which is separate from personal and family finances, human resource management in particular improves the skills and capabilities of human resources [11].

There is a production plan that is made both from determining the type of product, product quality and the number of products to be produced. In addition, management of agricultural products is certainly needed so that when entering the harvest season the farmers do not experience difficulties in marketing their agricultural products because middlemen are also present which causes difficulties in the life of the farming community, the middlemen buy agricultural products directly from farmers at low prices and resell them in the market at high prices so that the profits obtained by farmers decrease. Farmers also always prepare a financial budget to calculate the amount of income and expenditure needed. Financial management is carried out effectively and efficiently and adjusted to priority needs in agricultural production.

\subsection{The influence of the level of competitiveness on the development of business scale}

The level of competitiveness has a positive and significant effect on the development of MSME business scale in the agricultural sector in Soppeng district with a positive coefficient value of 0.324 and a significance value of 0.004 . This means that MSMEs need to increase their competitiveness in their business in order to survive in market competition. One of the efforts to be able to compete is to increase competitiveness, both the competitiveness of MSMEs and the competitiveness of their products through innovation. This is because the measurement of farm competitiveness is important to measure the ability of a farming commodity to generate maximum profits from the farming [21].

To produce competitive SMEs according to Russell and Millar there are five components, namely Cost, Quality, Flexibility, Time and Innovation. Farming costs are used efficiently and effectively and adjusted to production needs. In addition, there are quality improvement measures taken to increase agricultural production results. Business actors also adjust the right 
production time in agricultural businesses to avoid production failures. Agricultural products are produced according to community needs. In addition, there are also various types of products. Farming actors always pay attention to the quality of agricultural products needed by consumers. Innovative activities have also been carried out by farming actors by utilizing existing technology and providing the best service to buyers. innovation in agricultural products is carried out in order to attract buyers. Farmer competitiveness is the level of farmers' ability to produce agricultural products based on cost advantage. Competitiveness can be measured through two approaches, namely comparative advantage and competitive advantage. Comparative advantage measures the efficiency of a commodity based on economic analysis using shadow prices, while competitive advantage is used to measure the feasibility of an activity or private profit calculated based on private prices [2].

\subsection{Influence of Technology on the development of business scale}

The findings of this study also show that technology has a positive and significant effect on the development of the MSME business scale in the agricultural sector in Soppeng district with a positive coefficient value of 0.280 and a significance value of 0.003 . This means that there is a close influence between the use of technology and the development of business scale. technological developments will make the work of business actors easier. For example, in terms of promotion or marketing. Business actors can use the internet to do marketing on various available social media or marketplaces. This will increase the possibility of selling products and increase marketing areas.

One of the factors that causes an increase in production is the improvement of technology from the use of old technology to new technology in the form of production tools, consumption tools, or production inputs or consumption goods. The existence of new technology allows for increased production costs and increased risk and uncertainty. However, if these obstacles can be overcome, it can realize a greater increase in production. In addition, with modern agricultural technology it can increase agricultural production [13]. The application of technology in agriculture that has not been maximized is sometimes not caused by inadequate technology controlled, but sometimes influenced by inadequate facilities and infrastructure. Therefore, it requires direct assistance from the government because individual farmers have not been able to buy tractors by themselves [19]. There are several modern agricultural tools that can be used in the agricultural production process including tractors, water pumps and other modern agricultural tools. used in the production process is adjusted to the needs of the agricultural products produced. Lack of knowledge and skills in using technology will make farming difficult to develop.

\section{CONCLUSION}

The results of this study indicate that capital, quality of human resources, business management, level of competitiveness and technology have a positive and significant impact on the development of MSME business scale in the agricultural sector in Soppeng Regency. Agriculture can develop well if it is supported by capital, quality human resources, business management, level of competitiveness and adequate technology.

\section{ACKNOWLEDGMENTS}

We thank the anonymous reviewers who have provided constructive suggestions for improving this article.

\section{REFERENCES}

[1] Rohim, A., \& Kurniawan, I. (2017). Manajemen Usaha Dan Produksi Pada Usaha Mikro, Kecil Dan Menengah (UMKM) Di Desa Carang. Wulung Wonosalam. Journal Of Community Service, 1(1), 23-28.

[2] Dennis Karani, K., \& Wanjohi, J. (2017). Factors Influencing Marketing of Agricultural Produce Among Small-Scale Farmers: a Case of Sorhgum in Giaki Location, Meru County Kenya. International Journal of Economics, Commerce and Management United Kingdom, 8(8), 667. http://ijecm.co.uk/

[3] Nadziroh, M. N. (2020). Peran Sektor Pertanian Dalam Pertumbuhan Ekonomi Di Kabupaten Magetan. Jurnal AGRISTAN, 2(1), 52-60.

[4] Maswirahmah. (2011). Arahan Perencanaan Ketahanan Pangan Di Kabupaten Soppeng. 68, $70-$ 80

[5] Sulfaidah, \& Nurmilasari. (2021). Tranformasi Struktur Ekonomi Kabupaten Soppeng. Bulletin Of Economic Studies (BEST), 1(1), 23-32.

[6] Surianti, Irnayani, \& Hardianingsih, T. D. (2020). Sistem Produksi, Pengolahan Hasil Dan Pemasaran Pangi Di Kabupaten Soppeng. Jurnal Ilmiah Metansi "Manajemen Dan Akuntansi", 3(2), 16-22.

[7] Rahayu, E. S., Astirin, O. P., \& Suryanto. (2021). Membangun Sinergi antar Perguruan Tinggi dan Industri Pertanian dalam Rangka Implementasi Merdeka Belajar Kampus Merdeka". Seminar Nasional Dalam Rangka Dies Natalis Ke-45 UNS Tahun 2021, 5(1), 848-856.

[8] Susanto, I. D., \& Rondhi, M. (2021). Efek Inovasi Penyinaran Lampu Pada Usahatani Buah Naga Di Desa Bulurejo Kecamatan Purwoharjo Kabupaten Banyuwangi. Jurnal Komunikasi Dan Penyuluhan Pertanian, 1(2), 93-103.

[9] Hidayat, G. W. (2021). Faktor-Faktor yang Mempengaruhi Penerapan Panca Usahatani Padi Ladang Amfibi pada Petani Binaan Balai 
Pengkajian Teknologi Pertanian di Kabupaten Manokwari. Jurnal Triton, 12(1), 29-44. https://doi.org/DOI:

https://doi.org/10.47687/jt.v12i1.163 journal

[10] Suryantini, L. P., \& Sulindawati, N. L. G. E. (2020). Pengaruh Kualitas Sumber Daya Manusia, Penggunaan Informasi Akuntansi, Pemanfaatan Teknologi Informasi Dan Modal Pinjaman Terhadap Kinerja Umkm Di Kecamatan Buleleng. JIMAT (Jurnal Ilmiah Mahasiswa Akuntansi) Universitas, 11(2), 125-135.

[11] Risnawati, N. (2020). Pelatihan Manajemen Usaha Bagi UMKM Di Kabupaten Pacitan - Provinsi Jawa Timur. E-Coops-Day, 1(2), 111-114.

[12] Bismala, L. (2016). Model Manajemen Usaha Mikro Kecil dan Menengah (UMKM) untuk Meningkatkan Efektivitas Usaha Kecil Menengah. Jurnal Enterpreuner Dan Enterpreneurship, 5(1), 19-25.

[13] Pembangunan, J. E., Ekonomi, F., \& Ratulangi, U. S. (2019). Analisis Pengaruh Modal Dan Biaya Produksi Terhadap Pendapatan Umkm Di Kota Kotamobagu. Jurnal Berkala Ilmiah Efisiensi, 19(01), 56-67.

[14] Suganda, F. R., \& Kartiko, E. (2021). Analisis Komunikasi Tentang Faktor-Faktor Yang Sukaregang Kabupaten Garut. Jurnal Komunikasi, 7(1), 635-648.

[15] Ma'ruf, M., Ikhbaluddin, Suripto, \& Abdurohim4. (2021). Pengembangan Kapasitas (Capacity Building) Usaha Kecil Dan Menengah Bidang Pertanian Di Kecamatan Rancabungur Kabupaten Bogor. Jurnal Pembangunan Pemberdayaan Pemerintahan (J-3P), 6(1), 16-32. https://doi.org/Doi: https://doi.org/10.33701/j3p.v6i1.1512

[16] Giantari, I. G. A. K. (2020). The Role Of Government Policy, Entrepreneurship Orientation, Marketing Strategy And Its Impact On Strategic Competitiveness Of Silk Products And Marketing Performance. Journal Of Critical Reviews, 7(19), 9401-9417.

[17] Apriani, M., Rachmina, D., \& Rifin, A. (2018): Pengaruh Tingkat Penerapan Teknologi Pengelolaan Tanaman Terpadu (Ptt) Terhadap Efisiensi Teknis Usahatani Padi. Jurnal Agribisnis

Indonesia,
https://doi.org/10.29244/jai.2018.6.2.121-132

[18] Delmayuni, Hubies, M., \& Cahyadi Eko, R. (2017). STRATEGI PENINGKATAN DAYA SAING UMKM PANGAN DI PALEMBANG Strategies to Increase the Competitiveness of Food's Small Medium Enterprises (SMEs) in Palembang. Buletin Ilmiah Litbang Perdagangan, 11(N01), 97-122

[19] Amridha, Y., Heryanto, M. A., Saefudin, B. R., \& Awaliyah, F. (2019). The Analysis Of The Employee's Job Satisfaction And Performance In Private Agricultural Company (A Case On Pt Trisna Naga Asih, Subang). Mahatani, 2(2), 122130

[20] Pengajar, S., \& Agribisnis, D. (2016). Pengaruh Karakteristik Kewirausahaan terhadap Kinerja
Usaha Mikro, Kecil dan Menengah (UMKM) Gula Aren di Kabupaten Lombok Barat. Jurnal Penyuluhan, 12(1), 51-60.

[21] Fitriany, \& Abidin, Z. (2018). Analysis of Strategic Factors Affecting the Success of Small Enterprises in South Sulawesi. Kinerja, 22(2), 113-125. https://doi.org/DOI : $\quad 10.24002 /$ kinerja.v22i2.1807 2), $93-103$. 